This item was submitted to Loughborough's Research Repository by the author.

Items in Figshare are protected by copyright, with all rights reserved, unless otherwise indicated.

\title{
The au(I) catalyzed activation of allenamides and their subsequent transformation into chromanes: a method for the regiocontrolled addition to the alpha- and gamma-positions of the allene unit
}

\section{PLEASE CITE THE PUBLISHED VERSION}

http://dx.doi.org/10.1021/ol502178v

\section{PUBLISHER}

(c) American Chemical Society

\section{VERSION}

AM (Accepted Manuscript)

\section{PUBLISHER STATEMENT}

This work is made available according to the conditions of the Creative Commons Attribution-NonCommercialNoDerivatives 4.0 International (CC BY-NC-ND 4.0) licence. Full details of this licence are available at: https://creativecommons.org/licenses/by-nc-nd/4.0/

\section{LICENCE}

CC BY-NC-ND 4.0

\section{REPOSITORY RECORD}

Slater, Natasha H., Natalie J. Brown, Mark R.J. Elsegood, and Marc C. Kimber. 2019. "The Au(i) Catalyzed Activation of Allenamides and Their Subsequent Transformation into Chromanes: A Method for the Regiocontrolled Addition to the Alpha- and Gamma-positions of the Allene Unit". figshare. https://hdl.handle.net/2134/16851. 


\title{
The $A u(I)$ catalysed activation of allenamides and their subsequent transformation into chromanes: a method for the regio-controlled addition to the $\alpha$ - and $\gamma$-positions of the allene unit.
}

\author{
Natasha H. Slater, Natalie J. Brown, Mark R.J. Elsegood and Marc C. Kimber* \\ Department of Chemistry, Loughborough University, Leicestershire, LE11 3TU, U.K. \\ Supporting Information Placeholder
}

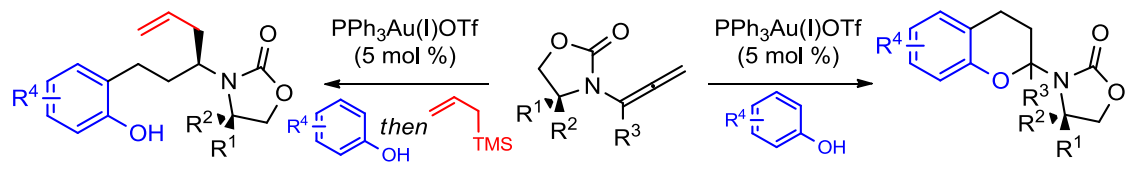

ABSTRACT: $\mathrm{Au}(\mathrm{I})$ activation of allenamides in the presence of phenols, leads to the formation of chromanes in moderate to good
yields. This catalytic process is dependent on the counter ion which facilitates the activation of the in situ formed imine. Further-
more, this iminium can be intercepted by trimethylallyl silane, via the Hosomi-Sakurai reaction, giving a formal procedure for the
regioselective intermolecular addition of two carbon nucleophiles to an allenamide at the $\alpha$ - and $\gamma$-positions.

Allenamides (1) are a unique class of allenes that can undergo selective electrophilic activation leading to the subsequent addition of nucleophiles at either the $\alpha$ - or $y$-positions of the allene unit (Scheme 1). ${ }^{1}$ The electrophilic activation of the allenamide can be achieved using a number of synthetic methods; including Brönsted acids, ${ }^{2}$ halogenation via treatment with $\mathrm{I}_{2}$ and $\mathrm{NIS},{ }^{3}$ oxidation (e.g. DMDO), ${ }^{4}$ or the use of metal catalysts; ${ }^{1 a}$ with cationic $\mathrm{Au}(\mathrm{l})$ salts proving to be one of the most facile yet mild methods for their activation. ${ }^{1 \mathrm{a}}$ The reactivity that allenamides display in the presence of cationic $A u(I)$ has led to this reaction manifold being successfully exploited in a number of powerful transformations. These include gold catalysed [2+2]- and [4+2]-cyclisations, ${ }^{2 h, 5,6}$ intra- and intermolecular hydroaminations, ${ }^{7}$ hydroarylation ${ }^{8}$ and hydroalkoxylation transformations, ${ }^{3 \mathrm{~d}, 9}$ Nazarov type cyclisations, ${ }^{10}$ and cyclopropanations; ${ }^{11}$ with all of these reactions presumably going via an $\mathrm{Au}(\mathrm{I})$ intermediate, such as 2, which is in turn generated by the electrophilic activation of the allenamide at the 3position by the $\mathrm{Au}(\mathrm{I})$ cation.

Scheme 1. Allenamide reactivity with electrophiles

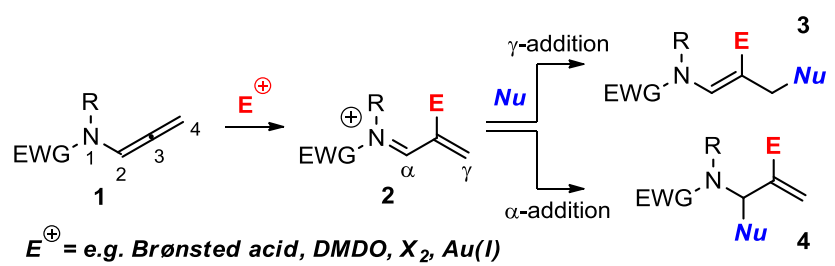

Within the context of intermolecular hydroarylation and hydroaminations reactions we have shown that the $\mathrm{Au}(\mathrm{I})$-catalysed addition of the nucleophile to mono-substituted allenamides exclusively occurs at the $Y$-position (6) (Scheme 2). ${ }^{7 b, 8 b}$ While this process gives $E$-enamides in high yields, and under mild reaction conditions, it also opens up the prospect of adding further nucleophiles, chemoselectively, to the enamide unit (7).

Scheme 2. Au(I) activation of allenamides

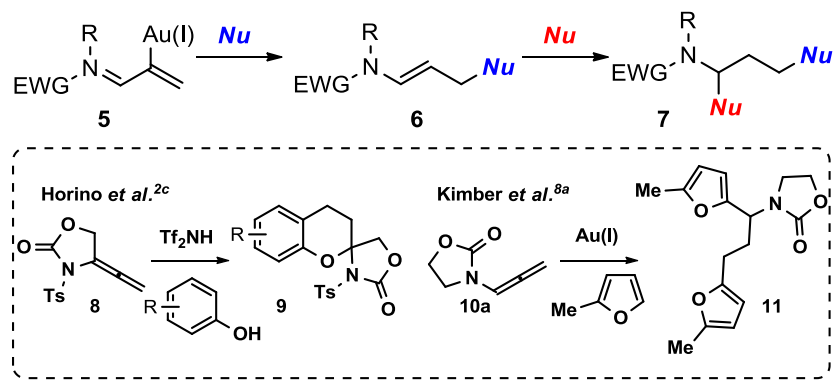

To date the only reported addition to both the $Y$ - and a-positions of an activated allenamide substrate is that of Horino and co-workers, who successfully demonstrated that allene sulfonamides of the type $\mathbf{8}$ 8,12 which are structurally related to allenamides but contain an additional electron withdrawing group directly attached to the nitrogen, successfully undergo a formal $[3+3]$ cycloaddition with phenols to deliver chromanes (9). ${ }^{2 C}$ The current authors also reported a related $\mathrm{Au}(\mathrm{I})$ catalysed bis-hydroarylation of $10 \mathrm{a}$; however, this bis-hydroarylation (11) occurred with no measurable chemoselectivity, and in modest overall 
yield. ${ }^{8 a}$ As a consequence within this study we would like to report our findings on the $\mathrm{Au}(\mathrm{I})$-catalysed formal $[3+3]$-cycloaddition of phenols to allenamides containing only one electron withdrawing group attached to the nitrogen, the role of the $\mathrm{Au}(\mathrm{I})$-counterion in the process, and the first regio-controlled intermolecular addition of two carbon nucleophiles to an allenamide at both the $\alpha$ - and $\gamma$-positions. The synthetic advantages of using an allenamides are (i) their ease of synthesis, (ii) their utility in diastereoselective reactions and, (iii) their flexibility in substitution and configuration; ${ }^{1 a, b}$ however, this is tempered by their reported decomposition in the presence of Brönsted acids. $^{8 \mathrm{~b}}$

We therefore began our study by investigating the addition of $p$-cresol to $10 \mathbf{a}$ using the mild activations conditions we have previously reported $(5 \mathrm{~mol} \%$ $\left.\mathrm{PPh}_{3} \mathrm{AuOTf}\right){ }^{7 \mathrm{~b}, 8 \mathrm{~b}, \mathrm{c}}$ Consequently, stirring 10a (1 equiv.) with $p$-cresol (12, 2 equiv.) at room temperature in $\mathrm{CH}_{2} \mathrm{Cl}_{2}$ gave the chromane 13 in a very respectable conversion of $91 \%$ and isolated yield of $88 \%$ (Scheme 4). The identity of $\mathbf{1 3}$ was ascertained by a combination of ${ }^{1} \mathrm{H},{ }^{13} \mathrm{C}$ NMR and infra-red spectroscopy; specifically the ${ }^{1} \mathrm{H}$ NMR showed a diagnostic doublet doublets at $5.68 \mathrm{ppm}(J=3.2$ and $10.0 \mathrm{~Hz})$ indicative of the $\mathrm{C}-\mathrm{H}$ of the aminal. Additionally, 13 proved to be crystalline and single crystal X-ray analysis was performed confirming its structure. ${ }^{13}$

Scheme 4. Chromane formation.

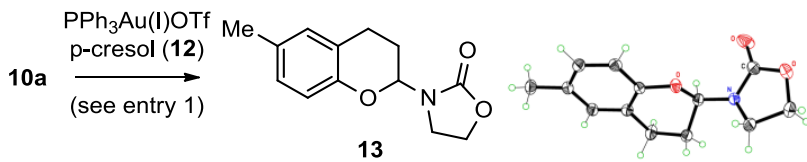

Table 1. Optimisation conditions for the formation of $13 .^{a}$

$\begin{array}{cccc}\text { entry } & \text { catalyst } & \text { equiv } & \text { conversion }^{b}[\%]^{c} \\ 1 & \mathrm{PPh}_{3} \mathrm{Au}(\mathrm{I}) \mathrm{OTf} & 2.0 & 91[88 \%]^{c} \\ 2 & \mathrm{PPh}_{3} \mathrm{Au}(\mathrm{I}) \mathrm{OTf} & 1.5 & 89 \\ 3 & \mathrm{PPh}_{3} \mathrm{Au}(\mathrm{I}) \mathrm{OTf} & 1.1 & 88[86 \%]^{c} \\ 4 & \mathrm{PPh}_{3} \mathrm{Au}(\mathrm{I}) \mathrm{BF}_{4} & 1.1 & 25 \\ 5 & \mathrm{PPh}_{3} \mathrm{Au}(\mathrm{I}) \mathrm{PF}_{6} & 1.1 & 26 \\ 6 & \mathrm{PPh}_{3} \mathrm{Au}(\mathrm{I}) \mathrm{NTf}_{2} & 1.1 & 82 \\ 7 & \mathrm{PPh}_{3} \mathrm{Au}(\mathrm{I}) \mathrm{Cl} & 1.1 & - \\ 8 & \mathrm{Ag}(\mathrm{I}) \mathrm{OTf} & 1.1 & 16 \\ 9 & - & 1.1 & - \\ 10 & \mathrm{Tf}_{2} \mathrm{NH} & 1.1 & 25^{e} \\ { }^{a} \mathrm{R} & & & \end{array}$

${ }^{a}$ Reactions run with $5.0 \mathrm{~mol} \%$ of catalyst ${ }^{14}$ in $\mathrm{CH}_{2} \mathrm{Cl}_{2}$ at room temperature for $16 \mathrm{~h}$ unless otherwise stated. ${ }^{b}$ Conversion was determined by ${ }^{1} \mathrm{H}$ NMR using trimethoxybenzene as an internal standard. ${ }^{c}$ isolated yield in brackets. ${ }^{d}$ No consumption of starting material was seen after $16 \mathrm{~h}$. ${ }^{e}$ Significant degradation of the allenamide 10a was evident.

We then optimised this process and in particular probe the nature of the $\mathrm{Au}(\mathrm{I})$-counterion (Table 1). We were able to reduce the amount of $p$-cresol to 1.1 equivalents with limited impact on conversion or isolated yield (entries $2 \& 3$ ). The importance of the counterion in the formation of the chromane product was ascertained with the reaction being undertaken with $\mathrm{PPh}_{3} \mathrm{Au}(\mathrm{l})$ and the counterions $\mathrm{BF}_{4}^{-}$and $\mathrm{PF}_{6}{ }_{6}$, respectively, which both gave a moderate conversion to 13 in $25 \%$ and $26 \%$ (entries $4 \& 5$ ), and also with $\mathrm{NTf}_{2}{ }^{-}$which gave a conversion to $\mathbf{1 3}$ on parity with the $\mathrm{OTf}^{-}$counterion example in entry 3 (entry 6 ). When the cyclisation was undertaken with $\mathrm{PPh}_{3} \mathrm{AuCl}$ no conversion was recorded (entry 7); however, when AgOTf was used this lead to a $16 \%$ conversion to 13 , presumably by the generation of $\mathrm{TfOH}$ on exposure to phenol (entry 8). Next we undertook the cyclisation in the absence of any catalysts which gave none of the desired product (entry 9), and the cyclisation was also undertaken under the conditions of Horino and coworkers (catalytic $\left.\mathrm{Tf}_{2} \mathrm{NH}\right)^{2 \mathrm{C}}$ which did deliver 13, but in a modest conversion of $25 \%$ (entry 10 ). It must be noted that significant amounts of degradation products were observed for entry 10 .

The results of this screen clearly show that the conditions in entry 3 are ideal for the formation of the chromane 13 from 10a, and as a consequence the scope of this transformation was next investigated (Table 2). Various phenols reacted smoothly with the allenamide $\mathbf{X}$ under the $\mathrm{PPh}_{3} \mathrm{Au}(\mathrm{I}) \mathrm{OTf}$ conditions, with the exception of 4-nitrophenol (entry 4). When the reaction was under taken with 4-bromophenol (18) at room temperature the desired chromane 19 was isolated in a modest yield of $28 \%$, which paralleled the resulted obtained by Horino. ${ }^{2 c}$ However, if the reaction was heated to $60{ }^{\circ} \mathrm{C}$ in dichloroethane this could be increased to an acceptable $62 \%$ (entry 3 ). When $m$-cresol (22) was used, an inseparable 2:1 mixture of 23a and 23b was obtained in $78 \%$ yield, with the predominant product 23a presumably being preferentially formed on steric grounds (entry 5). Pleasingly, 2,3,5trimethylbenzene-1,4-diol (30) added cleanly to the activated allenamide under our $\mathrm{Au}(\mathrm{I})$ catalysed conditions, providing chromane $\mathbf{3 1}$ in a good yield of $86 \%$ (entry 9), and as a consequence this gives a nice entry into the heterocyclic core of the tocopherols and tocotrienols. ${ }^{15}$ The 1,1-disubstituted allenamide 10b, synthesised from 10a, ${ }^{16}$ also participated in this transformation with 26, providing chromane 32, in good yield of $73 \%$ (entry 10 ). To end this screen, we investigated the use of chiral allenamide $10 \mathrm{c}$ to see if the stereogenic centre within the oxazolidinone would have any diastereomeric control in the formation of the chromanes. Treatment of $10 \mathrm{c}$ with $\mathbf{2 8}$ gave the chromane 33 in good yield of $72 \%$ and in a dr of $96: 4$, with the predominant diastereoisomer being confirmed by nOe (entry 11). Similarly, treatment of $10 \mathrm{c}$ with 26 also gave a predominant diatereoisomer $\mathbf{3 4}$ in good yield of $68 \%$ and a dr of 94:6 (entry 12). Surprisingly, treatment of $\mathbf{1 0} \mathbf{c}$ with 2,3,5trimethylbenzene-1,4-diol (30) did yield the desired chromane 35 in good isolated yield of $74 \%$, but in a modest dr of 3:1 (entry 13).

The mechanism of this formal [3+3] addition of phenols to allenamides under $\mathrm{Au}(\mathrm{I})$ catalysed conditions deserves discussion with respect to the counterion (Scheme 5). 
Table 2. Reaction scope for the $A u(I)$ catalysed chromane formation from allenamides. ${ }^{a}$

\begin{tabular}{|c|c|c|c|c|}
\hline entry & allenamide & nucleophile & product & $\begin{array}{l}\text { yield } \\
{[\%]^{b}}\end{array}$ \\
\hline 1 & $10 \mathrm{a}$ & 14: $\mathrm{R}=\mathrm{OMe}$ & 15: $\mathrm{R}=\mathrm{OM}$ & 70 \\
\hline 2 & $10 \mathrm{a}$ & 16: $R=H$ & 17: $\mathrm{R}=\mathrm{H}$ & 63 \\
\hline $3^{c}$ & $10 a$ & 18: $\mathrm{R}=\mathrm{Br}$ & 19: $\mathrm{R}=\mathrm{Br}$ & 62 \\
\hline 4 & $10 \mathrm{a}$ & 20: $\mathrm{R}=\mathrm{NO}_{2}$ & - & - \\
\hline 5 & $10 \mathrm{a}$ & 22 & $23 a: 23 b=2$ & 78 \\
\hline 6 & $10 \mathrm{a}$ & 24 & 25 & 72 \\
\hline 7 & $10 \mathrm{a}$ & 26 & 27 & 89 \\
\hline 8 & $10 \mathrm{a}$ & 28 & 29 & 72 \\
\hline 9 & $10 \mathrm{a}$ & Me & 31 & 86 \\
\hline 10 & $\begin{array}{l}\text { Me } \\
10 b\end{array}$ & 26 & 32 & 73 \\
\hline $11^{d}$ & $10 c$ & 28 & 33 & 72 \\
\hline $12^{d}$ & $10 \mathrm{c}$ & 26 & 34 & 68 \\
\hline $13^{d}$ & $10 \mathrm{c}$ & 30 & & 74 \\
\hline
\end{tabular}

${ }^{a}$ Reactions run with $5.0 \mathrm{~mol} \%$ of catalyst in $\mathrm{CH}_{2} \mathrm{Cl}_{2}$ at room temperature at $1 \mathrm{M}$ unless otherwise stated. ${ }^{b}$ Isolated yield. ${ }^{c}$ Reaction run at $60{ }^{\circ} \mathrm{C}$ in dichloroethane. ${ }^{d}$ Dr determined by ${ }^{1} \mathrm{H}$ NMR using the $\mathrm{CH}_{3}$ signal of the ipropyl group.
Scheme 5. Proposed mechanism.

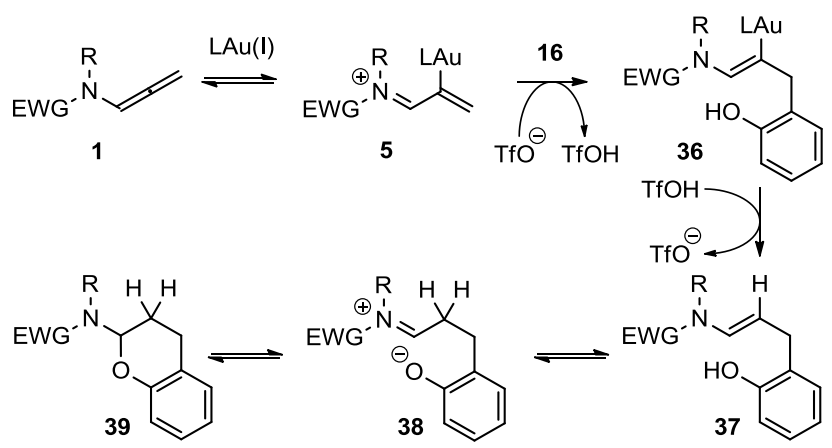

The initial activation of the allenamide 1 under cationic $\mathrm{Au}(\mathrm{I})$ conditions presumably gives $\mathbf{5}$. This then undergoes arylation with 16, giving the $A u(I)$ intermediate 36 and concomitant formation of $\mathrm{TfOH}$, which further promotes the proto-deauration to give the arylated enamide intermediate $\mathbf{3 7}$. The cyclisation of $\mathbf{3 7}$ to 39 is supported by an iminium peak at $9 \mathrm{ppm}$ in the crude products which may correspond 38 . The observation within the NMR of the crude products of an iminium peak presents an opportunity to intercept this iminium with a suitable external nucleophile. Accordingly, using the Hosomi-Sakurai reaction ${ }^{17}$ of acetals as a foundation we elected to introduce an equivalent allyltrimethysilane to the reaction upon conversion to the chromane (Scheme 6).

Scheme 6. Chemoselective addition to allenamides.

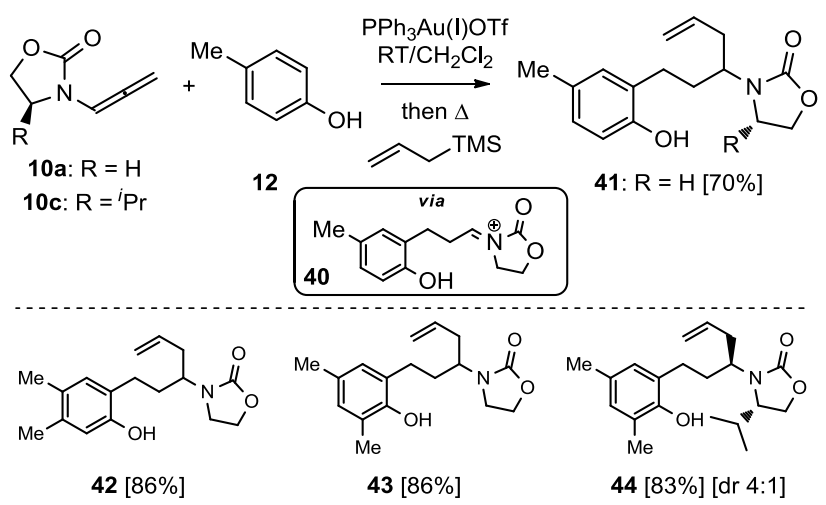

Initially, the reaction was left to stir at room temperature which gave $\mathbf{4 1}$ in a modest yield of $32 \%$; however, this could be increased to a yield of $70 \%$ if the reaction mixture was heated to reflux overnight. ${ }^{18}$ This procedure was then used to give the allylated products 42 and 43, both in satisfactory yields of $86 \%$. Additionally, when the chiral alleneamide 10c was used in this transformation the allylated product $\mathbf{4 4}$ was obtained in a yield of $83 \%$, and importantly in a dr of $4: 1$, implying that the presence of a stereogenic centre at the $\mathrm{C} 2$ of the oxazolidinone ring results in diastereoselectivity in the allyl addition to the iminium. In summary, we have shown that $A u(I)$ catalysis is suitable for the formal [3+3] addition of phenols to 
allenamides containing one electron withdrawing group. While the $\mathrm{Au}(\mathrm{I})$ catalysed hydroarylation proceeds as previously reported, the OTf $^{-}$counterion is key to the activation of the enamide, and the subsequent cyclisation to the chromane. Additonally, we have demonstrated that the in situ formed chromane can be allylated via the iminium, therefore giving a formal procedure for the regioselective intermolecular addition of two carbon nucleophiles to an allenamide to the $\alpha$ - and $\gamma$-positions. The use of this $\mathrm{Au}(\mathrm{I})$ catalysed approach for further functionalisation of allenamides and in intermolecular processes will be reported on in due course.

\section{ASSOCIATED CONTENT}

\section{SUPPORTING INFORMATION}

Experimental procedures, NMR spectra and characterization for all new materials. This material is available free of charge via the Internet at http://pubs.acs.org.

\section{AUTHOR INFORMATION}

Corresponding Author

* M.C.Kimber@1boro.ac.uk

Notes

The authors declare no competing financial interest.

\section{ACKNOWLEDGMENT}

The authors thank Loughborough University for financial support, Dr Mark Edgar and Dr Matthew Turner (both Department of Chemistry, Loughborough University) for NMR analysis, and Mass Spectral analysis respectively.

\section{REFERENCES}

(1) For reviews on allenamides see, (a) Lu, T.; Lu, Z.; Ma, Z. -X.; Zhang, Y.; Hsung, R. P. Chem. Rev. 2013, 113, 4862; (b) Wei, L.-L.; Xiong, H.; Hsung, R. P. Acc. Chem. Res. 2003, 36, 773; (c) Standen, P. E.; Kimber, M. C.Curr. Opin. Drug Discovery Dev. 2010, 13, 645; (d) De agostino, A.; Prandi, C.; Tabasso, S.; Venturello, P. Molecules 2010, 15, 2667.

(2) (a) Baikalova, L. V.; Zyryanova, I. A.; Tarasova, O. A.; Chipanina, N. N.; Shmidt, E. Yu.; Kashik, T. V.; Afonin, A. V.; Sinegovskaya, L. M.; Vashchenko, A. V.; Trofimov, B. A. Russ. J. Gen. Chem. 2003, 73, 1634; (b) Navarro-Vázquez, A.; Rodríguez, D.; Martínez-Esperón, M. F.; García, A.; Saá, C.; Domínguez, D. Tetrahedron Lett. 2007, 48, 2741; (c) Hashimoto, K.; Horino, Y.; Kuroda, S. Heterocycles 2010, 80, 187; (d) Hayashi, R.; Hsung, R. P.; Feltenberger, J. B.; Lohse, A. G. Org. Lett. 2009, 11, 2125; (e) Hayashi, R.; Feltenberger, J. B.; Lohse, A. G.; Walton, M. C.; Hsung, R. P. Beilstein J. Org. Chem. 2011, 7, 410; (f) Hayashi, R.; Feltenberger, J. B.; Hsung, R. P. Org. Lett. 2010, 12, 1152; (g) Berry, C. R.; Hsung, R. P.; Antoline, J. E.; Petersen, M. E.; Rameshkumar, C.; Nielson, J. A. J. Org. Chem. 2005, 70, 4038; (h) Lohse, A. G.; Hsung, R. P. Org. Lett. 2009, 11, 3430.

(3)(a) Noguchi, M.; Okada, H.; Watanabe, M.; Okuda, K.; Nakamura, O. Tetrahedron 1996, 52, 6581; (b) Zhu, Y.; Yin, G.; Hong, D.; Lu, P.; Wang, Y. Org. Lett. 2011, 13, 1024 ; (c) Zhu, Y.; Yin, G.; Sun, L.; Lu, P.; Wang, Y. Tetrahedron 2012, 68, 10194; (d) Hyland, C. J. T.; Hegedus, L. S. J. Org. Chem. 2006, 71, 8658.

(4)(a) Rameshkumar, C.; Xiong, H.; Tracey, M. R.; Berry, C. R.; Yao, L. J.; Hsung, R. P. J. Org. Chem. 2002, 67, 1339; (b) Xiong, H.; Hsung, R. P.; Berry, C. R.; Rameshkumar, C. J. Am. Chem. Soc. 2001, 123, 7174; (c) Krenske, E. H.; Houk, K. N.; Lohse, A. G.;
Antoline, J. E.; Hsung, R. P. Chem. Sci. 2010, 1, 387; (d) See reference 1(a) for a review of this activation pathway.

(5)(a) Li, X.-X.; Zhu, L.-L.; Zhou, W.; Chen, Z. Org. Lett. 2012, 14, 436; (b) Faustino, H.; Bernal, P.; Castedo, L.; López, F.; Mascareñas, J. L. Adv. Synth. Catal. 2012, 354, 1658; (c) Suárez-Pantiga, S.; Hernández-Díaz, C.; Piedrafita, M.; Rubio, E.; Gonzáleza, J. M. Adv. Synth. Catal. 2012, 354, 1651.

(6) For a review see (a) Lopez, F; Mascareñas, J. L. Chem. Soc. Rev. 2014, 43, 2904; (b) Lopez, M.; Mascareñas, J. L. Beilstein J. Org. Chem. 2013, 9, 2250; (c) Lopez, M.; Mascareñas, J. L. Beilstein J. Org. Chem. 2013, 7, 1075; (d) Faustino, H.; López, F.; Castedo, L.; Mascareñas, J. L. Chem. Sci. 2011, 2, 633; (e) Francos, J.; GrandeCarmona, F.; Faustino, H.; Iglesias-Sigüenza, J.; Díez, E.; Alonso, I.; Fernández, R.; Lassaletta, J. M.; López, F.; Mascareñas, J. L. J. Am. Chem. Soc. 2012, 134, 14322; (f) Montserrat, S.; Faustino, H.; Lledos, A.; Mascareñas, J. L.; Lopez, F.; Ujaque, G. Chem., Eur. J. 2013, 19, 15248; (g) Faustino, H.; Alonso, I.; Mascareñas, J. L.; Lopez, F. Angew. Chem. Int. Ed. 2013, 52, 6526.

(7) (a) Manzo, A. M.; Perboni, A. D.; Broggini, G.; Rigamonti, M. Tetrahedron Lett. 2009, 50, 4696; (b) Hill, A. W.; Elsegood, M. R. J.; Kimber, M. C. J. Org. Chem. 2010, 75, 5406; (c) Broggini, G.; Borsini, E.; Fasana, A.; Poli, G.; Liron, F. Eur. J. Org. Chem. 2012, 3617.

(8) (a) Watanabe, T.; Oishi, S.; Fujii, N.; Ohno, H. Org. Lett. 2007, 9, 4821; (b) Kimber, M. C. Org. Lett. 2010, 12, 1128; (c) Singh, S.; Elsegood, M. R. J.; Kimber, M. C. Synlett 2012, 23, 565; (d) Pirovano, V.; Decataldo. L.; Rossi, E.; Vicente, R. Chem. Commun., 2013, 49, 3594; (e) Jia, M.; Cera, G.; Perrotta, D.; Monari, M.; Bandini, M. Chem. Eur. J. 2014, 20, 9875.

(9) (a) Horino, Y.; Takata, Y.; Hashimoto, K.; Kuroda, S.; Kimurab, M.; Tamaru, Y. Org. Biomol. Chem. 2008, 6, 4105; (b) González-Gómez, A.; Domínguez, G.; Pérez-Castells, J. Eur. J. Org. Chem. 2009, 5057.

(10) Ma, Z. -X.; He, S.; Song, W.; Hsung, R. P. Org. Lett. 2012 14,5736 .

(11) Sabbatani, J.; Huang, X.; Veiros, L. F.; Maulide, N. Chem. Eur. J. 2014, DOI: 10.1002/chem.201402935.

(12) For an in depth discussion on the reactivity of $\mathbf{8}$ see Horino, Y.; Kimura, M.; Tanaka, S.; Okajima, T.; Tamaru, Y. Chem. Eur. J. 2003, 9, 2419 and referenced cited within.

(13) Crystal data for 13: $\mathrm{C}_{13} \mathrm{H}_{15} \mathrm{NO}_{3}, M=233.26$, triclinic, $P \overline{1}, a=$ 10.7856(14), $b=11.0756(15), c=12.1131(16) \AA, \alpha=69.1857(19), \beta$ $=65.3217(18), \gamma=63.0462(19)^{\circ}, V=1147.1(3) \AA^{3}, Z=4, \mu(\mathrm{Mo}-\mathrm{K} \alpha)$ $=0.096 \mathrm{~mm}^{-1}, 17838$ reflections measured, 7213 unique, $R_{\text {int }}=$ $0.0216, R_{1}\left[F^{2}>2 \sigma\left(F^{2}\right)\right]=0.0409, w R_{2}$ (all data) $=0.1175$. Two similar molecules in the asymmetric unit. CCDC 1015343 contains the supplementary crystallographic data for this paper. These data can be obtained free of charge from The Cambridge Crystallographic Data Centre via www.ccdc.cam.ac.uk/data request/cif.

(14) The catalysts $\mathrm{PPh}_{3} \mathrm{AuOTf}, \mathrm{PPh}_{3} \mathrm{AuBF}_{4}, \mathrm{PPh}_{3} \mathrm{AuPF}_{6}$ were preformed from $\mathrm{PPh}_{3} \mathrm{AuCl}$ and $\mathrm{AgOTf}, \mathrm{AgBF}_{4}$ and $\mathrm{AgPf}_{6}$, respectively. Additionally, $\mathrm{PPh}_{3} \mathrm{AuNTf}_{2}$ was purchased from a commercially supplier.

(15) Couladouros, E. A.; Moutsos, V. I.; Maria Lampropoulou, M.; James L. Little, J. L.; Hyatt, J. A. J. Org. Chem. 2007, 72, 6735.

(16) Xiong, H.; Hsung, R. P.; Wei, L.-L.; Berry, C. R.; Mulder, J. A.; Stockwell, B. Org. Lett. 2000, 2, 2869.

(17) (a) Hosomi, A.; Miura, K. Bull. Chem. Soc. Jpn. 2004, 77, 835. (b) Hosomi, A. Acc. Chem. Res. 1988, 21, 200. (c) Hosomi, A.; Sakurai, H. Tetrahedron Lett. 1976, 17, 1295.

(18) To support the formation of the iminium $\mathbf{4 0}$ during the $\mathrm{Au}(\mathrm{I})$ catalysed arylation, the purified chromane $\mathbf{1 3}$ was treated with allyltrimethylsilane in the absence of Lewis acid, which failed to give 41. Allylation was achieved with excess $\mathrm{TiCl}_{4}$ gaving 41 in an acceptable isolated yield of $68 \%$. 
